\title{
ISLAM DAN SEKSUALITAS: BIAS GENDER DALAM HUMOR PESANTREN
}

\author{
Sumadi \\ Pascasarjana Institut Agama Islam Darussalam Ciamis \\ Email:sumadi2009@gmail.com
}

\section{Abstract}

Humor becomes an important part in institutionalizing the culture of pesantren. Yet, the humor in pesantren often ignores the values that respect gender equality. Understanding Islam pesantren patriarchy becomes the root for establishing the themes of humor that exploit women's bodies and sexuality. Study of humor and sexuality in pesantren in Indonesia are still unnoticed. This study used a qualitative research approach with a feminist analysis in pesantren Priangan West Java. The results of this study showed that Islam patriarchy in pesantren institutionalized within the themes of humor created by kiai, teachers, and students in pesantren. As the implication, humor in pesantren contains the values and ideology of gender bias in the form of stereotyping, objectification, and the domestication of women. Dominant objects in pesantren humor are the body and female sexuality. The body becomes the center of worship and praise despite the epicenter definition, identity, and control on women by men.

Humor menjadi bagian penting dalam pelembagaan budaya pesantren. Akan tetapi humor-humor di pesantren sering mengabaikan nilai-nilai yang menghargai kesetaraan gender. Pemahaman Islam pesantren yang patriarki menjadi akar pembentukan tema-tema humor yang mengeksploitasi tubuh dan seksualitas perempuan. Kajian humor dan seksualitas di lingkungan pesantren di Indonesia termasuk yang luput dari perhatian. Kajian ini menggunakan pendekatan penelitian kualitatif dengan analisis feminis di pesantren Priangan Jawa Barat. Hasil penelitian ini menunjukkan bahwa patriarkisme Islam pesantren terlembagakan dalam tema-tema humor yang dibuat kiai, guru, 
dan santri di pesantren. Implikasinya humor-humor di lingkungan pesantren mengandung tata nilai dan ideologi bias gender berupa stereotip, objektifikasi, dan domestifikasi perempuan. Objek yang dominan humor di pesantren yaitu tubuh dan seksualitas perempuan. Tubuh menjadi pusat puja dan puji, tetapi menjadi episentrum pendefinisian, pemberian identitas, dan kontrol pada perempuan yang dilakukan laki-laki.

Keywords: Islam; pesantren; gender; perempuan; humor.

\section{Pendahuluan}

Pesantren merupakan lembaga pendidikan yang berciri khas Islam. Sejak didirikan di Indonesia pesantren memiliki kajian khusus yang tidak dimiliki insitusi pendidikan lain yaitu pendalaman tentang agama Islam. Walaupun perkembangan saat ini mayoritas pesantren telah mengakomodasi berbagai pendidikan formal, pendalaman agama Islam (taffaquh fiddin) tetap menjadi inti pendidikan pesantren. Islam menjadi asas berbagai kajian ilmu pengetahuan yang dikembangkan pesantren.

Sebagai wadah pendalaman Islam, pesantren mewajibkan para muridnya tinggal selama 24 jam di dalam lingkungan pesantren. Tujuannya agar para murid memahami budaya pesantren secara utuh, yaitu sejak bangun tidur sampai tidur lagi dengan teladan kiai sebagai pimpinan pesantren. Oleh karena itu interaksi antara anggota pesantren, yaitu kiai, guru dan santri berjalan secara intim.

Dalam pengenalan budaya pesantren dan Islam salah satu bentuk interaksi yang digunakan adalah humor-humor pesantren. Humor dipandang sebagai bentuk budaya untuk menghibur sekaligus sebagai media untuk menyampaikan pesan-pesan Islam. Seorang kiai, guru, atau santri menyampaikan humorhumornya di dalam pembelajaran Islam, dalam ceramah-ceramah keagamaan, nasihat pernikahan, dan di panggung-panggung hiburan pada acara-acara besar pesantren.

Dalam proses interaksi sosial di pesantren gender dikonstruksi dan dilembagakan secara budaya dalam bentuk humor-humor. Akan tetapi seringkali humor dalam proses enkulturasi budaya pesantren cenderung tidak mempertimbangkan aspek penghargaan pada kesetaraan gender. Pertimbangan utama humor lebih pada aspek lucu dan menghibur sehingga pesan Islam yang disampaikan sampai pada tujuan yang diharapkan. Padahal isinya terdapat banyak humor yang bias gender mengukuhkan stereotip dan objektifikasi 
terhadap perempuan. Terdapat humor-humor di lingkungan pesantren di wilayah Priangan Jawa Barat yang menunjukkan perempuan dikonstruksi secara bias gender.

Dalam penjelasan Crawford (2003) humor menjadi alat untuk membangun diskursus dan interaksi sosial. Humor menjadi alat konstruksi gender yang menggambarkan identitas laki-laki dan perempuan secara diskriminatif. Humor yang digunakan oleh laki-laki dan perempuan atau oleh satu jenis kelamin baik laki-laki maupun perempuan saja menjadi alat mengkonstruksi gender.

Humor menjadi alat produksi dan reproduksi budaya di lingkungan pesantren. Humor ditempatkan sebagai media yang dianggap efektif dalam menyampaikan pesan-pesan Islam. Secara tidak sadar humor-humor yang digunakan dalam interaksi pembentukan budaya di pesantren menunjukkan pembentukan identitas yang stereotip terhadap perempuan. Dalam kajian Gunning (2001: ii) humor adalah bagian penting dalam pembentukan sebuah budaya dalam organisasi. Humor memiliki beberapa fungsi penting dalam pembentukan budaya sebab humor memiliki fungsi dalam pembentukan kejiwaan dalam diri seseorang, dalam anggota sebuah organisasi/latar sosial dan pembentukan interaksi sosial. Humor yang dengan eksploitasi psikis dan tubuh perempuan sebagai objeknya dalam isu gender memiliki peran dalam memperkuat stereotip perempuan yang membentuk budaya bias gender di lingkungan pesantren. Konsekuensinya humor dengan eksploitasi psikis dan fisik tubuh perempuan sebagai objeknya dapat dikategorikan sebagai bentuk kekerasan terhadap perempuan yang berdampak pada pelembagaan bias gender secara natural (tidak sadar).

Kajian ini memfokuskan pada Islam dan seksualitas yang menjadi dasar pembentukan humor di pesantren. Berbagai bentuk humor menunjukkan konstruksi seksualitas dan obejektifikasi perempuan yang bias gender di pesantren. Pemilihan pesantren dalam kajian ini yaitu kategori pesantren besar dan memiliki sejarah panjang pengaruhnya pada masyarakat yang berada di wilayah Priangan Jawa Barat. Pesantren dalam penelitian ini pesantren modern dan pesantren salafiyah (tradisional), yaitu Pesantren Darussalam Ciamis, Pesantren al-Hasan, Pesantren Arrisalah Cijantung, Pesantren Miftahul Huda Manonjaya Tasikmalaya, Pesantren al-Hamidiyah Langkap Lancar Pangandaran, Pesantren Miftahul Huda II, dan Pesantren Miftahul Ulum Maarif Ciamis.

Pendekatan yang digunakan dalam kajian ini adalah pendekatan kualititatif dengan perspektif feminis (Reinharz, 2005: 21, Hughes, 2002: 48106, Jackson, 2009: 21-55). Cara mendapatkan data yaitu dengan observasi 
pada humor-humor yang digunakan pesantren dalam proses pembelajaran, ceramah, dan nasihat pernikahan. Wawancara mendalam dilakukan dengan para ustadz dan pengurus pesantren. Dokumentasi diperoleh melalui bukubuku humor yang diterbitkan pesantren, foto kegiatan, dan rekaman kegiatan pesantren. Semua data dianalisis dengan analisis isi feminis. Pembahasan tentang humor di pesantren dengan pendekatan feminis dan analisis gender di Indonesia masih luput dari perhatian dan sulit ditemukan sehingga kajian ini penting untuk dilakukan.

\section{Islam Bias Gender di Pesantren}

Islam yang bias gender di pesantren ditandai dengan dominasi pemahaman Islam patriarki. Cara pandang Islam pesantren sampai saat ini masih mempertahankan pemikiran Islam yang konservatif. Implikasinya dominasi budaya patriarki masih mengakar kuat di lingkungan pesantren. Relasi laki-laki dan perempuan yang terdapat dalam kitab-kitab di pesantren dianggap sebagai ketentuan baku yang tidak perlu mendapat kritik dan penyesuaian zaman. Secara historis pesantren memang mengembangkan budaya patriarki, sebab pesantren pada awalnya hanya diperuntukan untuk laki-laki (Hasyim, 2010: 317). Pada awalnya pesantren di Indonesia hanya untuk laki-laki. Cara pandang yang diskriminatif menempatkan laki-laki yang layak menuntut berbagai ilmu agama yang terkait dengan ranah publik dan individual. Sementara perempuan dipandang cukup memperoleh ilmu yang terkait dengan kesalehan individual sebagai seorang perempuan.

Implikasinya perempuan secara hirarkis dalam budaya pesantren tidak mendapat tempat yang setara. Urusan-urusan publik menjadi hak laki-laki. Oleh karena itu kepemimpinan pesantren secara turun menurun menjadi haknya anak laki-laki. Seorang anak perempuan yang memiliki kemampuan kepemimpinan dan manajerial yang kuat tidak akan memperoleh hak kuasa menjadi pemimpin pesantren. Perempuan menjadi kelompok yang tersubordinasi dengan ditempatkan pada ruang-ruang domestik. Ajaran Islam yang dikembangkan di pesantren dianggap telah final dalam menempatkan laki-laki perempuan. Dalam kerangka ini, Islam pesantren adalah Islam yang dikembangkan dalam budaya yang memberi keistimewaan pada lakilaki. Perempuan secara agama dikonstruksi pada ruang-ruang yang sempit. Perempuan sebagai pengabdi pada laki-laki. Ketaatan total perempuan pada laki-laki menjadi budaya tidak tergoyahkan sampai saat ini. Keluasan ilmu yang dimiliki perempuan tidak serta merta menjadikannya memiliki hak ijtihad 
dan penentu kebijakan seperti yang dimiliki oleh laki-laki. Sebab otoritas ijtihad dan kekuasaan politik dipandang sebagai haknya laki-laki.

Dalam interaksi sosial, budaya pesantren mendefinisikan perempuan sebagai mahkluk yang memiliki kekuatan intelektual dan kecepatan fisik yang lebih rendah dibanding dengan laki-laki.

....Janten titik beratna ka istri. Pamegeut mah jarang. Dina fikih oge seeur pisan dibahas istri pamegeut. Contohna missal tentang persaksian istri mah upami janten saksi kirang kuat. Istri dua pamegeut cekap hiji. Upami saksi zina kan pamgeut jumlahnya kedah opat, berarti upami istri kedah dalapan. Nya kitu deui dina waris sareng sanes kanten. Pantes da pamegeut mah ngagendong upami istri kan cekap ngajingjing. [... berbagai aturan titik beratnya kepada perempuan. Laki-laki jarang mendapat penekanan. Contohnya tentang persaksian, persaksian perempuan tidak kuat. Perempuan dua, laki-laki cukup satu. Apalagi saksi-saksi lain. Saksi perbuatan zina harus empat laki-laki, jika perempuan maka jumlahnya harus delapan. Begitu juga dalam bab-bab waris dan bab-bab hukum lainnya. Pantas sebab tanggung jawab laki-laki lebih berat (pamegeut mah ngagendong) dan tanggung jawab perempuan lebih ringan (upami istri kan cekap ngajingjing)] (wawancara dengan guru perempuan pesantren).

Pembagian tugas, waris, dan persaksian dikategorikan tugas laki-laki. Laki-laki ditempatkan lebih superior dengan berbagai kelebihan fisik dan intelektualitasnya dibandingkan perempuan. Wilayah-wilayah publik dipandang pantas bagi laki-laki, sebab laki-laki kekuatannya dianggap dua kali lipat dibandingkan perempuan. Perempuan diidentifikasi sebagai makhluk yang inferior, bertanggung jawab pada wilayah-wilayah domestik. Pemahaman bahwa laki-laki memikul (pamegeut mah ngagendong) dan perempuan cukup menjinjing (upami istri kan cekap ngajingjing) mengganggap dunia laki-laki adalah dunia yang menyangkut superioritas. Perempuan menganggap dunianya yang inferior tidak diperlukan seperti kapasitas yang dimiliki laki-laki. Menurut kerangka teoretik (Anshari, 1997: 24) dari peran gender terjadi proses sosialisasi yang membentuk identitas gender yaitu pencitraan perilaku yang seharusnya dimiliki dan ditampilkan oleh seseorang menurut jenis kelamin yang bersangkutan di pesantren. Oleh karena itu, jika terdapat perbedaan perilaku menurut jenis kelamin, yang bersangkutan dianggap sebagai penyimpangan perilaku. Peran perempuan dan peran laki-laki diaplikasikan dalam bentuk yang nyata menurut kultur yang dianut dan diterima di lingkungan pesantren.

Agama Islam dipandang sebagai agama yang membangun relasi yang seimbang antara laki-laki dan perempuan. Tuhan dianggap telah menciptakan secara sosial perempuan berbeda dengan laki-laki. Ayat-ayat al-Quran dan hadis sebagai sumber ajaran Islam dianggap telah sempurna tanpa harus menafsirkan

el Harakah Jurnal Budaya Islam Vol. 19 No.1 Tahun 2017 
dan memberi penjelasan. Ruang kritik terhadap teks-teks ajaran Islam yang mendominasi dunia pesantren dianggap sebagai pelanggaran atas sakralitas agama. Teks-teks dianggap suci dengan argumentasi yang dibangun pesantren. Berbagai kitab yang menjadi referensi Islam adalah buatan oleh yang suci dan berakhlak mulia. Oleh karena itu memberi kritik atas kitab-kitab yang telah mengatur relasi laki-laki dan perempuan dianggap sama dengan melecehkan khazanah Islam pesantren.

Sumber-sumber pemelihara budaya yang membangun konstruksi perempuan dan laki-laki secara patriarki di pesantren berupa kitab kuning. Dilihat dari aspek pengarang (Bruinessen, 1994: 142-145) 100 kitab kuning yang populer di pesantren di Indonesia tidak terdapat pengarang perempuan. Artinya perspektif perempuan dalam khazanah pesantren tidak mendapat tempat. Kepentingan-kepentingan laki-laki yang terdapat dalam kitab-kitab kuning disosialisasikan secara terus menerus dan turun menurun dalam perjalanan panjang sejarah pesantren. Dalam budaya pesantren para generasi penerus diwajibkan untuk memelihara budaya pesantren. Kitab kuning dipandang sebagai ciri khas budaya pesantren. Dalam pandangan pesantren jika tidak ada kitab kuning, maka dianggap pesantren telah hilang dari peradaban Indonesia. Akan tetapi sumber-sumber kitab kuning yang diajarkan di pesantren memuat nilai-nilai yang bias gender. Akar masalahnya kitab-kitab kuning yang membahas tentang konstruksi perempuan berasal dari hadis-hadis yang misoginis (Marhumah, 2015).

Kitab-kitab kuning yang berpengaruh di pesantren di wilayah Priangan Jawa Barat di antaranya adalah kitab fikih dan kitab-kitab tentang etika perempuan. Fikih-fikih yang digunakan di pesantren di wilayah Priangan Jawa Barat adalah fikih-fikih yang feodal dan patriakis. Fikih yang mengandung tatanan nilai patriarki dipandang sebagai "kitab suci" yang tidak perlu mendapat koreksi. Ajaran fikih yang sebagian besar memuat nilai-nilai yang mendiskriminasi perempuan dianggap sebagai tata nilai yang baku yang tidak memerlukan kontektualisasi jaman. Dalam fikih Islam pesantren perempuan nilainya dikategorikan setengah laki-laki. Fikih yang patriarki menjadi sumber kesahihan tatanan sosial yang mengatur laki-laki dan perempuan di pesantren. Padahal disiplin ilmu yang paling representatif menggambarkan fenomena sosial di pesantren tersebut ada dalam fikih (Mughits, 2008: 3).

Pada aspek etika Islam, tubuh perempuan menjadi sumber untuk memandang perempuan secara sosial. Bias gender Islam pesantren memandang tubuh dan seksualitas perempuan menjadi sumber membangun identitas 
perempuan. Dalam pandangan Islam pesantren perempuan dianggap memiliki syahwat lebih besar dibanding dengan laki-laki. Tubuh dan suara perempuan dipandang mengandung fitnah sehingga tidak layak tampil di publik yang luas. Dalam pandangan para guru (ustadz) di pesantren bahwa perbedaan yang paling kontras antara laki-laki dan perempuan terletak pada kekuatan syahwat perempuan dan laki-laki.

...syahwat budak istri teh salapan, jadi mun ngaji atawa acara lain di pasantren dihijikeun anu lewih bahaya teh sabenerna awewe. Mun lalaki hiji. Tapi istri mah diberi anugrah rasa malu atawa kaera, jadi kuat nahan henteu sapertos pameget. Janten upami ngaos dihijikeun antara pamegeut istri saleresna istri anu gaduh dorongan syahwat ageung (wawancara dengan guru laki-laki di pesantren). [syahwat perempuan itu jumlahnya sembilan, sedangkan laki-laki jumlahnya satu sehingga nafsu syahwat perempuan lebih besar dibanding dengan laki-laki. Hanya kelebihannya jika perempuan diberi rasa malu. Rasa malu ini yang menjadikan perempuan pandai menyembunyikan diri atau menahan diri. Sebetulnya jika pada acaraacara atau pengajian digabung antara laki-laki dan perempuan sejatinya perempuan yang memiliki dorongan hawa nafsu lebih tinggi].

Perempuan dianggap memiliki kekuatan syahwat seksual lebih tinggi atau lebih kuat dibanding dengan laki-laki, yaitu laki-laki satu sedangkan perempuan sembilan. Perbedaannya dengan laki-laki bahwa perempuan memiliki kekuatan nafsu seksual sembilan kali lipat dibanding dengan lakilaki. Perempuan dianggap memiliki dorongan seksual lebih tinggi. Itulah dasar pelarangan kegiatan-kegiatan pesantren dipisahkan antara perempuan dan laki-laki. Tetapi di sisi lain kekuatan pertahanan perempuan dalam menjaga hasrat seksual dianggap lebih kuat dibanding laki-laki karena para perempuan memiliki kekuatan rasa malu sehingga perempuan dianggap lebih pandai menyembunyikan nafsu dibanding laki-laki. Rasa malu dianggap sebagai kekuatan yang dapat menyembunyikan keinginan untuk mengekspresikan dorongan seksual yang besar para perempuan.

Anggapan bahwa perempuan memiliki syahwat yang lebih besar dibanding dengan laki-laki secara tidak disadari berdampak pada munculnya anggapan kebutuhan perempuan yang paling utama adalah kebutuhan nafsu seks. Misalnya dalam prosesi pesta pernikahan di lingkungan pesantren, aspek seksualitas perempuan menjadi topik utama yang diperbincangkan. Salah seorang kiai dalam nasihat pernikahan menjelaskan tentang sosok laki-laki calon suaminya telah memiliki cukup umur dan kesanggupan untuk menikah dengan bekal pengetahuan dan ilmu dari pesantren. Tetapi dari semua bekal tersebut sesungguhnya bekal yang paling penting itu "nyaeta anu ngarengkol dina calana kanggo panganten istri" [alat kelamin laki-laki yang penting bagi

el Harakah Jurnal Budaya Islam Vol. 19 No.1 Tahun 2017 
seorang perempuan]. Ungkapan ini adalah peribahasa yang mengandung makna nilai-nilai stereotip seksualitas sebagai kebutuhan utama perempuan. Kejantanan dianggap menjadi syarat terpenting bagi pengantin dibanding dengan syarat-syarat lain dalam pernikahan.

Dalam penjelasan masyarakat pesantren yang menyangkut tubuh atau bagian tubuh selalu dihubungkan dengan tubuh perempuan. Tubuh selalu menjadi objek sasaran pembahasan. Dalam proses kajian Islam di pesantren, kiai yang menyampaikan materi tentang tauhid (akidah) menggunakan perempuan sebagai objek. Tauhid adalah materi akidah yang berkaitan dengan keyakinan dan kepercayaan terhadap Tuhan dan hal-hal gaib dalam agama. Salah satu makhluk gaib yaitu jin yang digambarkan rupanya sangat buruk terutama bibirnya yang jelek. Dengan humornya sang kiai menjelaskan "leheung mun biwir awewe mah" (akan lebih menarik dan beruntung jika bibirnya adalah bibirnya seorang perempuan yang cantik). Bibir perempuan dipandang aspek tubuh yang seksi sehingga paling menarik untuk dieksploitasi dibanding dengan bagian tubuh yang lain.

Tata nilai yang bias gender dengan menempatkan patriarkisme Islam di pesantren terus dipertahankan seiring dengan kepentingan laki-laki atas pesantren. Sebuah institusi pesantren laksana sebuah kerajaan. Setiap ganti generasi, pesantren memiliki aset ekonomi, politik, dan sosial yang besar bagi para pewarisnya. Laki-laki lahir menjadi sosok yang memiliki kepentingan untuk menguasai berbagai aset-aset penting pesantren. Kontestasi kepemimpinan lakilaki dan perempuan dikonstruksi sebagai haknya laki-laki. Laki-laki ditempatkan sebagai pewaris mutlak kepemimpinan pesantren. Anak laki-laki seperti putra mahkota dalam kerajaan yang secara otomatis menjadi pewaris tahta tertinggi pesantren. Oleh karena itu dalam budaya pesantren selagi masih ada anak laki-laki perempuan dipandang tidak memiliki hak untuk menjadi pemimpin yang dapat melanjutkan perjalanan pesantren.

Budaya yang bias gender di lingkungan pesantren dipertahankan untuk memperkuat kepentingan-kepentingan kaum laki-laki di pesantren. Humor-humor diproduksi dalam budaya pesantren berlatar Islam yang dikembangkan dalam budaya patriarki sehingga berdampak pada proses produksi dan reproduksi budaya yang menguntungkan laki-laki. Humor memperkuat kontrol secara budaya terhadap indentitas dan hak-hak perempuan. Dalam kajian Bareeca (1991, dalam Gilbert, 2004), disebutkan bahwa terdapat hubungan humor dengan kekuasaan dan kontrol dalam masyarakat terhadap perempuan. Dalam penelitian Nielsen (1993, dalam Gilbert, 2004) orang yang melakukan 
atau menyampaikan humor sesungguhnya ia sedang mengontrol orang yang mendengarkan, sebaliknya orang yang mendengarkan humor sesungguhnya ia sedang dikontrol orang yang menyampaikan humor. Oleh karena itu humorhumor di pesantren secara budaya dapat menjadi alat yang mengontrol para perempuan agar di posisi yang terpinggirkan dengan memiliki identitas gender yang dikategorikan berbeda secara sosial dengan laki-laki.

\section{Bias Gender dalam Humor Pesantren}

Humor di pesantren yang mengandung bias gender pada perempuan terlembaga dalam budaya pesantren yang disosialisasikan melalui interaksi sosial sehari-hari oleh para santri, guru, dan kiai, dalam ceramah umum oleh para kiai di pesantren, maupun dalam pembelajaran, dan nasehat dalam acara pernikahan. Pada awalnya tema-tema humor di pesantren dalam bentuk tradisi lisan santri, pengurus dan kiai. Mayoritas pesantren di Priangan yang termasuk dalam penelitian ini tidak membukukan naskah humor, seperti Pesantren Darussalam, Arrisalah, Cijantung, Miftahussalam, Cikanyere, al-Hasan, alHamidiyah Langkaplancar, Pesantren Miftahul Ulum Maarif Ciamis, dan lain-lain. Humor disampaikan secara lisan sebagai bentuk komunikasi yang mengedepankan aspek lucu oleh santri, guru, dan kiai dalam kajian Islam di pesantren.

Namun ada satu pesantren, yaitu Pesantren Miftahul Huda Manonjaya Tasikmalaya, yang secara khusus mempublikasikan tema-tema humor dalam bentuk buku yang dicetak resmi. Buku cetak humor dibuat, diedit dan naskahnya disahkan oleh anggota dewan kiai. Naskah-naskah humor yang dicetak dijual ke para santri dan didistribusikan ke cabang-cabang pesantren Miftahul Huda sebagai bagian dari referensi dakwah Islam. Di pesantren Miftahul Huda tema-tema humor ditampilkan pada acara-acara khusus yang dibawakan grup humor santri bernama Batscom.

Grup humor Bastcom mirip dengan bahasa Inggris, dan juga mirip nama alat dapur yaitu baskom. Bastcom adalah singkatan dari Barudak Santri Komedi Pesantren Miftahul Huda. Bastcom sebagai grup humor tampil dalam berbagai kegiatan di pesantren. Misalnya pada acara hari-hari besar Islam seperti Muharaman, acara kenaikan kelas, acara puncak perlombaan antar santri dan tampil di acara-acara masyarakat seperti dalam hiburan pesta khitanan dan pernikahan. Pelembagaan humor di pesantren Miftahul Huda Manonjaya melalui grup lawak Bastcom dipimpin secara khusus oleh pengurus pesantren. Pembimbing dan pengarah grup humor Bastcom adalah dewan 
kiai dan para kiai muda di lingkungan Miftahul Huda Manonjaya. Humor pesantren Miftahul Huda, di antaranya cerdok (cerita pondok atau cerita pendek), singrey (singkatan heurey yaitu singkatan yang mengandung humor) dan gusal (lagu-lagu tiruan).

Humor bagi pesantren merupakan bentuk ekspresi lucu sebagai alat memperkuat komunikasi dakwah dan pembelajaran Islam. Terdapat tiga tema humor di pesantren yaitu bernuansa kritik sosial, realitas kehidupan di pesantren, dan tema tentang perempuan. Contoh tema tentang kritik sosial dalam cerdok (cerita pondok-cerita pendek) yaitu tentang DPR:

Pantesan loba jalma nu pakoer-koer, silih tojer, nepi ka ngagalaleser, masang baliho meni ngajalejer, bendera pageber-geber, merean kaos teu kedah meser, mikeunan duit ngidul ngaler, ngabelaan jadi DPR, geuning lamun jadi DPR, hirup moal kateter, dibere mobil panther, motor tiger, imah gedong teu kudu manjer, hayang nanaon kari gesek langsung tokcer, ngan teu saeutik nu ngagaloler, mabok nepika teller, gantung diri nepi ka meler, mun teu jadi DPR... (Bastcom Barudak Santri Comedi, 2010: 1011). [Pantas banyak orang yang saling mengalahkan (adu isu), saling sikut dan saling tendang sampai saling menggeser, memasang baliho sampai berjejer-jejer, memasang bendera dengan kibaran-kibaran yang tinggi, memberi kaos tanpa harus membeli, berkeliling memberikan uang kepada masyarakat karena ingin jadi anggota DPR, ketika sudah jadi DPR hidup senang tanpa kesusahan diberi mobil panther, motor tiger, diberi rumah mewah tanpa uang muka, ingin apa saja tinggal gesek uang mengalir, tetapi banyak yang tidak suka menenggak minuman keras, ada juga yang gantung diri karena tidak jadi anggota DPR].

Selain tema-tema kritik sosial tentang kehidupan sosial politik bangsa Indonesia dan realitas pesantren, tema tentang perempuan mendominasi tema humor di pesantren. Tema-tema yang menempatkan perempuan dan tubuh perempuan sebagai objek humor melembagakan ideologi bias gender dengan penekanan pada stereotip, objektifikasi, dan domestifikasi terhadap perempuan. Perempuan dipuja-puji tubuhnya, tetapi dihinakan derajat dan hak-haknya. Bias gender dalam humor-humor pesantren dijabarkan sebagai berikut.

\section{Stereotip Terhadap Perempuan}

Stereotip terhadap perempuan dalam humor di lingkungan pesantren menempatkan tubuh dan sifat-sifat citra negatif perempuan sebagai objek humor. Perempuan beserta tubuh dan sifat-sifatnya menjadi objek tema humor yang dianggap menghibur, lucu, kocak, dan biasa. Dengan penempatan perempuan sebagai objek secara dominan dalam tema-tema humor dianggap lebih menghibur dibanding tema laki-laki. Stereotip terhadap perempuan 
dalam humor-humor pesantren memberikan label negatif. Narasi humor yang dibuat kalangan pesantren menggambarkan perempuan sebagai manusia yang berada dalam kuasa harta laki-laki. Perempuan dipandang lemah sehingga akan selalu tunduk pada laki-laki yang berharta sekalipun usianya tua renta. Kuasa laki-laki atas harta mengandung arti kuasanya yang mutlak atas perempuan. Dengan harta laki-laki ditempatkan sebagai manusia berhak atas siapapun perempuan yang dipilihnya. Sebaliknya perempuan pada posisi yang lemah berada dalam posisi harus menerima atas pilihan laki-laki. Perempuan berada dalam keadaan yang pasif dan tertindas secara natural oleh laki-laki.

Sebenarnya perempuan memiliki harga yang tinggi di hadapan laki-laki. Tetapi harga tinggi perempuan pada tubuhnya, bukan pada harkat dan derajat sosial perempuan. Perempuan dikonstruksi dengan harga yang tinggi dengan mitos kecantikan. Tubuh menjadi alat standar harga seorang perempuan. Misalnya tema humor yang secara khusus dibuat oleh salah seorang anggota dewan kiai pesantren tentang Aki-aki Ompong (seorang kakek tua renta dan giginya ompong) dan tema Jalma Kaya (orang kaya raya):

Aki-aki Ompong..Lamun boga imah sigrong, balong ngemplong, mobil ngadangong, najan pipi kemong, huntu ompong, parawan oge pasti noong, komo randa nu nong-nong (Tohir, 2007:7). [...Jika punya rumah mewah, kolam yang luas, mobil mewah yang terpakir di rumah, walapun sudah tua dengan gigi ompong, seorang perempuan pasti akan tertarik apalagi jika berstatus janda].

Jalma Kaya... Bru di juru, bro dipanto, ngalayah di tengah imah, imah tembok, sawah ledok, pamajikan denok montok, rea beras awak waras, si jabrig di pipir, si jambrong di kolong, rawey bewengeun, rambay alaeun, lubak libuk kebon lobak kalebok (Tohir, 2007:6). [...penuh harta, di pojok rumah harta, di depan pintu harta, di tengah-tengah rumah penuh dengan harta kekayaan. Rumahnya terbuat dari tembok (bukan bilik bambu), sawah luas dengan kondisi tanah subur, istri cantik dan molek, padi melimpah, badan sehat, si Jabrig di pinggir, si Jambrong di kolong, banyak pilihan untuk dimakan, banyak tanaman untuk dipanen, kebun yang luas, seperti kebun lobak yang dapat dinikmati oleh orang kaya]. Dalam Aki-aki Ompong dan Jalma Kaya perempuan ditempatkan sebagai objek laki-laki. Laki-laki yang kaya raya dengan berbagai harta benda walaupun sudah ompong dengan kekayaannya para perempuan dari perawan sampai janda pasti akan tertarik. Artinya perempuan dalam tema ini diidentifikasi sebagai sosok yang lemah, memiliki ketergantungan yang tinggi pada laki-laki, dan laki-laki dapat membeli perempuan dengan harta yang dimilikinya.

Di tema humor yang kedua ukuran kekayaan seorang laki-laki dilihat dari kepemilikan perempuan. Yaitu seorang perempuan yang memiliki postur tubuh yang cantik, dan molek). Itulah kriteria perempuan yang berhak menjadi 
seorang istri. Pesan humor ini dalam budaya kehidupan pesantren, tubuh perempuan menjadi identitas penting gambaran dari kekayaaan laki-laki. Tema-tema humor perempuan seperti tema neng Elis, jablay, selebritis, dan iman kurupuk memberi pesan yang memperkuat stereotip pada perempuan yang menjadi episentrum penggoda laki-laki.

Neng Elis, wanoja urang ciamis, awakna jangkis rupana geulis, senyumna manis, da biwirna ipis, persis artis nu mapahna teh siga sedan Altis, kira-kira poe Kemis kuring kenalan ka neng elis, dugi ayeuna bayangna dugi ka lapis, ngecewis dina manah meni tiis (Bastcom Barudak Santri Comedi, 2010:13-14). [Neng Elis gadis orang Ciamis, tubuhnya tinggi dan langsing, jika berjalan mirip sedan Altis. Kira-kira hari Kamis saya berkenalan dengan neng Elis, sampai hari ini bayangannya terus menghantui, berdialog dengan hati setiap saat].

Dengan judul "Neng Elis" tema humor ini secara eksplisit menunjukkan stereotip terhadap perempuan. Perempuan dalam bait-bait tema ini secara seksualitas menjadi daya pikat yang kuat bagi laki-laki. Tema neng Elis tidak mengungkapkan kualitas hidup seorang perempuan, misalnya karena kepandaiannya, ilmunya, karyanya atau keahliannya. Tetapi menilai perempuan pada pemujaan atas tubuhnya yang langsing, senyumnya yang manis, dan aspek tubuh lain yang seksi. Tidak diungkap aspek-aspek dari keberdayaan dan kompetensi seorang perempuan. Definisi dan eksistensi perempuan disamakan dengan tubuh perempuan. Nilai seorang perempuan dalam kehidupan sosial dianggap sebanding dengan keindahan tubuhnya. Tetapi pada sisi lain kehebatan tubuh perempuan dianggap bencana sosial bagi kaum laki-laki.

Penguatan stereotip perempuan sebagai penggoda laki-laki tergambar dalam tema iman kerupuk berikut.

Iman Kurupuk. Iman teh ulah kawas kurupuk, teu kaop kacaian ngarumpunyuk, teu kaop kapanasan ngarumpuyuk, dimana kahapuk iman teh ambruk, di mana katalipuk iman the ti kusruk, komo biasana mah lalaki mah palebah jam dua isuk ningali awewe anu seksi-seksi nu wungkul make handuk, katingali awakna meni ngabentuk, susuna buled siga suuk, ngagupaian bari pura-pura batuk, ngajak du duan bari ngaringkuk, dina kasur anu empuk, sok sanajan loba rametuk, tapi imin mah angguk-angguk, tah nu kitu iman teh iman anu muruluk, kawas sukro murag kulutuk-kulutuk (Bastcom Barudak Santri Comedi, 2010:8-9).[Iman seperti kerupuk, terkena air sedikit mengerut. Ketika terkena pukulan akan hancur. Jika terkena terpaan iman akan ambruk, apalagi seorang laki-laki yang pada jam dua pagi melihat perempuan seksi yang hanya memakai handuk, terlihat bentuk lekuk tubuh dan dadanya, walaupun banyak nyamuk tetap saja bergairah. Itulah gambaran iman yang lemah].

Tema humor ini ide dasarnya tentang religiusitas seseorang yaitu tentang iman yang lemah yang digambarkan dengan salah satu jenis makanan, yaitu 
kerupuk sebagai simbol iman yang lemah. Kerupuk makanan yang mudah hancur bila terkena air menjadi gambaran kekuatan iman yang lemah akan mudah goyah dengan sedikit godaan. Jenis godaan yang meruntuhkan iman adalah perempuan, khususnya perempuan yang memiliki tubuh molek.

Stereotip pada humor ini menempatkan secara seksual tubuh perempuan sebagai sumber yang dapat meruntuhkan iman seorang laki-laki. Iman yang berdasar pada hubungan antara seorang manusia dengan Tuhannya akan dapat dihancurkan oleh pesona keindahan tubuh perempuan. Keindahan tubuh perempuan yang merupakan puncak ciptaan Tuhan atas makhluknya dipandang sebagai sumber malapetaka. Perempuan diposisikan sebagai makhluk yang serba salah. Keindahan tubuhnya dianggap sumber kenikmatan tetapi pada sisi yang berbeda ditempatkan sebagai sumber godaan.

Stereotip pada humor pesantren dengan menempatkan perempuan sebagai bencana sosial yaitu sosok penggoda laki-laki. Dalam khazanah pesantren secara teologis perempuan dianggap sejajar dengan makhluk yang merusak kehidupan laki-laki. Tiga faktor yang menjadi sumber malapetaka laki-laki, yaitu harta, tahta, dan wanita (Azis, 2008: 18). Dalam konteks ini stereotip tubuh perempuan dianggap fitnah. Fitnah adalah potensi-potensi yang dapat berakibat buruk baik bagi diri perempuan atau laki-laki. Dalam kerangka Strowaser (2001: 127) "fitnah" yang dilekatkan pada perempuan menjadi semacam konsep anarki sosial atau kekacauan sosial yang ditimbulkan oleh tubuh perempuan. Implikasinya konsep fitnah terhadap tubuh perempuan bahwa jenis kelamin perempuan dan tubuhnya mengakibatkan ketidakstabilan sosial.

\section{Objektifikasi Seksualitas Perempuan}

Humor di pesantren mengandung stereotip terhadap perempuan dengan identitas sebagai objek seksual laki-laki. Harta yang paling berharga bagi perempuan dihubungkan dengan kejantanan. Dalam humor di nasehat pernikahan misalnya muncul humor: yang dibutuhkan perempuan itu ATM (Alat Tusuk Manual=zakar), jengkol peda-na kanggo panganten istri, nyaeta anu ngarengkol dina calana kanggo panganten istri, Mobil Fiat Mobil VW, Teu Kuat Hayang Ngewe [Tidak sabar ingin segera hubungan intim]. ATM, nu ngarengkol dina calana, mobil Fiat-mobil VW adalah nama lain dari alat kelamin laki-laki yang dipandang sebagai kebutuhan pokok perempuan pasca pernikahan.

Seksualitas tubuh perempuan menjadi objek humor pesantren. Bagian tubuh perempuan yang sensitif menjadi sasaran humor di lingkungan pesantren.

el Harakah Jurnal Budaya Islam Vol. 19 No.1 Tahun 2017 
Misalnya humor tentang androk atau dari bawahan pakaian perempuan. Androk menjadi tema yang dianggap lucu bagi para santri dan anggota pesantren lainnya. Dengan bahasa yang dicampur antara bahasa Sunda dan Indonesia perempuan dikonstruksi dengan tema androk yang digambarkan dalam humor berikut ini:

Wahai androk, dulu bentukmu mengembang seperti batok, yang dipotong memakai golok, kau sangat panjang bagaikan balok, dan tebal seperti tembok, sehingga tidak mudah ditengok, oleh mata-mata jorok, tapi kau semakin pondok (pendek), pahanya yang montok, tidak sedikit laki-laki yang mencoba merampok, kemaluanmu yakni tempat keluar orok, wahai pengguna anrok, apakah imanmu sudah menjadi rontok, sehingga kemaluanmu tidak lagi kao patok (Bastcom, 2010: 2).

Dalam tema humor Ema jeung Bapa [Ibu dan Bapak] tentang besarnya pengorbanan orang tua terhadap anaknya. Kedua orang tua berjuang siang malam bahkan sampai kurang tidur hanya untuk anaknya. Konteks ketika menceritakan pengorbanan ibu yang melayani sang suami dimunculkan sebagai tema humor ini. Secara lengkap humor yang ditampilkan adalah sebagai berikut:

...Teu aya nu pang ageungna jasa, iwal ti bapa jeung ema, bapa ngabelaan benta ti beres Isya, nepi ka jam dua, pas tatangga taribra, meakeun sakabeh tanaga, nepika ngocor kesangna, kajeun tiris baju calana dibuka, Ema oge ukur capena, dina waktu nu lumayan lila, dintindihan beurat kacida ku bapa, diperes otak, tanaga, oge dada, nepika ditojos ku benda anu sagede cau nangka, malah nepi ka olabna... (Bastcom Barudak Santri Comedi, 2010: 3-4).

[tidak ada jasa yang paling besar, kecuali jasa bapak dan ibu, bapak begadang sampai waktu Isya, sampai jam dua di saat tetangga sedang nyenyak tidur, menghabiskan seluruh tenaga, sampai mandi keringat, walaupun cuaca dingin baju dan celana dibuka, ibu hanya mendapat kesengsaraan dengan lelah tingkat tinggi, ditimpa badan bapak yang berat, diperas otak, tenaga, dan tubuhnya, sampai ditusuk dengan benda sebesar pisang nangka, sampai kuwalahan....]. Tema yang menunjukkan perempuan sebagai objek seksual digambarkan dalam humor tema Istri Ditiung [perempuan berkerudung]. Dengan tema istri ditiung, perempuan digambarkan:

Mun ningal istri ditiung, hawa betah ingkah ge embung, sok sanajan nempona nangtung, karaosna teh asa ngapung, komo mun akhlaqna teh agung, irungna mancung, awakna jangkung, bodina melengkung, kulit bodas batan tipung, sigana mun boga kabingung bakal leungit langsung, mun daek dikawin kuring moal kaduhung (Bastcom Barudak Santri Comedi, 2010: 4-5). [Jika melihat perempuan berkerudung, suasananya menjadikan betah dan membuat orang malas pergi, serasa melayang, apalagi jika akhlaknya agung, hidungnya mancung, tubuhnya tinggi semampai, kulitnya putih melebihi tepung, orang yang melihatnya jika memiliki masalah akan hilang. Jika mau dikawin denganku pasti tidak akan menyesal]. 
Sosok perempuan yang menjadi dambaan yang digambarkan adalah sosok perempuan yang memiliki kriteria fisik tinggi semampai, hidung mancung, kulit putih. Jika persyaratan-persyaratan fisik seperti itu terpenuhi, maka inilah perempuan yang paling ideal untuk dinikahi laki-laki. Kriteria perempuan dengan persyaratan tertentu yang berhak dipilih laki-laki muncul pada tema humor berikut.

...Jablay pinggulmu memang bohai, tubuhmu indah semampai, sekali ngagupai orang-orang terbuai, bahkan nepi ka ngelai atawa ngacay, tapi sayang kau hanya seorang jablay, martabatmu jauh seperti lalay, bahkan lebih bejat dari tupai, kehormatanmu kau jual seperti siomay, yang dijual bari smapay, bari ngagorowok bari palay-palay...bertobatlah wahay jablay sebelum ajalmu sampai (Bastcom Barudak Santri Comedi, 2010: 6-7).

Kata jablay secara sosial memiliki makna yang negatif bagi perempuan. Humor ini sarat dengan eksploitasi seksual dan mengandung unsur kekerasan terhadap perempuan. Jablay merupakan singkatan jarang dibelai yang ditujukan kepada perempuan. Pada perkembangan selanjutnya kata jablay dilekatkan pada perempuan tuna susila atau perempuan nakal yang dianggap kesepian dan terus mencari mangsa laki-laki.

Istilah jablay memiliki makna yang secara budaya bersifat ekploitatif terhadap perempuan yang mengandung nilai-nilai ketimpangan gender. Dengan konsep jablay menunjukkan perempuan kebutuhannya adalah seksual, sehingga jika kebutuhan seksualnya tidak terpenuhi dia akan menjadi perempuan nakal yang kehausan seksual dan tidak bermoral. Dalam tema jablay itu memberi pesan bahwa kelompok orang yang senang menjual diri dan mengekploitasi seksualitas tubuh konteksnya terletak pada kaum perempuan. Gelar jablay hanya dilekatkan pada perempuan.

Para perempuan yang berprofesi artis dikonstruksi secara stereotip sebagai perempuan yang nakal. Identitas yang dilekatkan pada artis adalah perempuan yang menjual tubuhnya yang seksi.

Selebritis, ngaran-ngaran selebritis moal lepas ti awewe geulis, lalaki nu altletis, pakaian nu arawis, dangdanana siga turis, pokokna mah seksi habis, ningali susu jeung pingping teh gratis, da tiap poe katingali dina TV gratis, da tiap poe katingali dina TV meni laris, dina film mistis, film humoris, teu kaliwat dina kuis, meni kuat sing kacewis, nu ngamera meni ngabaris, reporter ge ngudag-ngudag dugika geubis, selebritis selebritis (Bastcom Barudak Santri Comedi, 2010: 16-17). [Selebritis, namanya selebritis tidak akan lepas dengan perempuan yang cantik, laki-laki yang atletis, memakai pakaian yang mahal, tampilannya seperti turis, melihat buah dada dan paha gratis, karena di TV setiap hari disaksikan secara gratis, sangat laris, di film mistis, film humoris, tidak terlewat di dalam kuis, reporter yang lari-lari sampai jatuh, selebritis...selebritis..]

el Harakah Jurnal Budaya Islam Vol. 19 No.1 Tahun 2017 
Objektifikasi seksualitas perempuan muncul pada humor tema ini, perempuan ditempatkan menjadi sosok yang memiliki pekerjaan dengan sumber penghasilan dari mengeksploitasi tubuhnya. Artis atau selebritis adalah area para perempuan yang menempati ruang untuk menjual tubuhnya. Dengan mendasarkan ide humor berbagai kasus yang menimpa para artis di Indonesia, gelar selebritis perempuan termasuk negatif. Selebritis diberi label perempuan yang seksi dan nakal. Dalam tema humor ini diuraikan identitas perempuan yang menjadi artis dengan objektivikasi seksual yaitu seksi dengan pakaian yang terbuka. Perempuan diposisikan dengan citra yang buruk pada dunia hiburan sehingga timbul anggapan bahwa perempuan yang aktif dalam dunia hiburan adalah para perempuan nakal dan tidak bermoral.

Dalam pandangan analisis gender bahasa yang digunakan dalam sebuah kelompok, institusi, organisasi dan masyarakat seperti pesantren berkecenderungan memiliki tradisi yang panjang dalam melanggengkan stereotip terhadap perempuan. Ini menyebabkan sulitnya perubahan untuk berpihak atau seimbang terhadap perempuan. Jeppersen (dalam Talbot, 2010: 177) menjelaskan sebagai fakta dalam dunia bahasa bahwa perempuan berkontribusi terhadap bahasa untuk mengurus kemurniannya menurut penyusutan naluriah mereka dari ekspresi vulgar dan kasar, sedangkan kontribusi-kontribusi laki-laki merupakan tenaga, imajinasi dan kreatifitas. Akhirnya bahasa yang digunakan oleh laki-laki dan perempuan membangun signifikansi laki-laki. Sebaliknya bahasa yang digunakan laki-laki dan perempuan membentuk kebodohan atas perempuan. Dalam konteks kajian ini, implikasinya bahasa-bahasa yang biasa digunakan laki-laki, jika digunakan perempuan akan menjadi 'cela' atau sesuatu yang negatif. Sebaliknya bahasa-bahasa yang pada hakikatnya mencela perempuan dianggap biasa dan natural yang tidak merugikan perempuan.

\section{Domestifikasi Perempuan}

Domestifikasi pada perempuan terjadi ketika para perempuan secara normatif dan takdir dikategorikan lebih inferior dibandingkan laki-laki. Pandangan bahwa perempuan lebih inferior tidak hanya menurut laki-laki tetapi juga menurut para perempuan. Dari masalah inferior secara fisik sampai dengan inferior masalah intelektual. Para perempuan pesantren yang secara intelektualnya melebihi laki-laki, seperti beberapa ustadzah/guru perempuan yang memiliki kemampuan dan penguasaan terhadap berbagai ilmu agama dan ilmu pengetahuan lainnya, para perempuan tetap merasa sebagai makhluk yang kapasitas akalnya di bawah laki-laki. Anggapan yang sama terhadap 
perempuan oleh laki-laki dan perempuan berpotensi semakin memperkuat para perempuan memperoleh pembedaan secara sosial yang menjadikan posisinya tetap di wilayah domestik.

Domestifikasi perempuan dalam humor pesantren dengan menempatkan perempuan pada tempat yang tersubordinasi. Jika humor-humor temanya tentang pemimpin, orang berilmu, dan orang kaya konteksnya adalah laki-laki. Tetapi jika humor temanya tentang pengabdian, kesetiaan, dan pengorbanan pasangan konteksnya menunjukkan pada perempuan.

Ilmu. Elmu mangrupa hiji sarana, pikeun nangtungkeun bagjana jalma, loba contona, jalma nu sangsara, gara-gara teu boga ilmu elmu dina boga jiwa raga, tapi mun jalma geus pinuh ku pangabisa, luhur kanyahona, darajat luhur boga wibawa, teu kudu ngumbara jauh-jauh ka Saudi Arabia, ngabelaan ngudag-ngudag harta, sabab harta datang nyalira, oge teu kudu saembara, komo mun pasea, neangan wanoja percaya teu percaya teu percaya wanoja eta, nu bakal kabita, ka goda, ka jalma nu elmuna loba, naon sababna? (Bastcom Barudak Santri Comedi, 2010: 19-20). [Ilmu merupakan sarana untuk menentukan bahagianya seseorang. Banyak contohnya, orang yang sengsara sebab tidak memiliki ilmu. Tetapi jika orang sudah pandai dengan memiliki berbagai ilmu, derajatnya tinggi, memiliki wibawa luhur, tidak harus mengembara ke Saudi Arabia untuk mendapatkan harta, sebab bagi orang berilmu harta akan datang dengan sendirinya. Para perempuan akan tergoda dengan orang yang banyak ilmunya, apa sebabnya?] Domestifikasi pada perempuan dalam humor ini adalah tentang tema ilmu konteksnya kepada laki-laki. Teks humor ini menempatkan laki-laki menjadi sosok yang berdaya dengan ilmu. Penguasaan ilmu dan berbagai pengalaman identik dengan laki-laki. Perempuan menjadi sosok yang lemah tidak berdaya. Sebab salah satu kehebatan laki-laki yang berilmu, ia akan menjadi rebutan dan pujaan perempuan. Ketinggian intelektualitas dan ilmu yang dilekatkan pada laki-laki secara budaya memberikan konstruksi budaya pada masayarakat bahwa orang yang berilmu dan memiliki keahlian menjadi haknya kaum laki-laki. Laki-laki sebagai pewaris atas ilmu yang dalam interaksi sosial memiliki kuasa atas perempuan. Sebaliknya perempuan menjadi objek dari laki-laki yang beridentitas sebagai manusia yang berilmu.

Di masa-masa selanjutnya humor yang dilembagakan akan berdampak pada pembentukan sebuah latar budaya. Artinya humor-humor yang bernuansa nilai-nilai yang bias gender akan membangun komunikasi yang bias gender di lingkungan pesantren yang membentuk ketimpangan gender. Secara keseluruhan bias gender terhadap perempuan di dalam humor pesantren memilki dua pesan penting, yaitu pertama, semakin meneguhkan laki-laki pada posisi yang superior dengan nilai-nilai yang makin meninggikan posisi

el Harakah Jurnal Budaya Islam Vol. 19 No.1 Tahun 2017 
laki-laki; kedua, pemaknaan perempuan (woman mainstreaming) sebagai objek seksualitas menjadi tema yang dominan. Humor dalam kajian komunikasi merupakan bagian penting dalam sebuah pembentukan budaya. Humor dalam konteks interaksi sosial merupakan cerminan dari sebuah budaya melalui sosialisasi nilai-nilai yang panjang dalam sebuah komunitas atau masyarakat. Humor di lingkungan pesantren tidak sekedar humor yang tidak memiliki konsekuensi budaya. Humor adalah bentuk produksi dan reproduksi sebuah budaya dalam organisasi, institusi pendidikan, dan masyarakat.

Dalam tema humor pesantren tubuh dan seksualitas perempuan dianggap sebagai objek sentral dalam mendefinisikan gender. Tubuh perempuan diidentifikasi sebagai identitas dan sifat perempuan. Oleh karena itu tubuh menjadi pusat yang membentuk secara budaya terhadap laki-laki dan perempuan. Dalam proses panjang tubuh perempuan dan konstruksi gender, Carson (2010: 147) memberi penjelasan secara teoretis bahwa relasi laki-laki dan perempuan diformulasikan melalui tubuh. Tubuh perempuan dijadikan dasar untuk membuat teori, tindakan-tindakan yang secara khusus ditujukan pada perempuan. Perbedaan relasi gender secara konvensional dilekatkan pada tubuh perempuan. Laki-laki dianggap sebagai kelompok yang superior baik tubuh maupun pemikirannya. Akibatnya proses-proses biologis seperti mensturasi, emosional, kehamilan dilekatkan secara besar-besaran terhadap tubuh perempuan sehingga menjadi dasar mendefinisikan perempuan. Ini berdampak pada pembedaan pembagian peran sosial yang timpang antara laki-laki dan perempuan.

\section{Simpulan}

Dominasi cara pandang Islam yang diskriminatif pada perempuan di pesantren menjadi proses enkulturasi budaya yang membentuk perilaku, interaksi, dan tatanan sosial pesantren yang patriarkis bias gender. Kitab-kitab kuning dianggap sebagai sumber tata nilai yang mengatur laki-laki perempuan secara diskriminatif ditempatkan sebagai teks suci yang tidak memberi ruang kritik.

Humor sebagai media penyebaran nilai-nilai Islam dengan mengeksploitasi seksualitas perempuan memberi penguatan pada stereotip, objektifikasi, dan subordinasi pada perempuan. Humor menjadi alat pelembagaan secara natural atas marjinalisasi perempuan. Seiring dengan kepentingan laki-laki Islam dan humor yang awalnya menjadi alat eksploitasi seksualitas, akhirnya jalin 
berkelindan dengan kepentingan politik laki-laki dalam mempertahankan kuasanya.

Oleh karena itu pengembangan diskursus Islam yang ramah perempuan harus dimuat dalam kurikulum pesantren yang terstruktur dan pesantren. Humor disusun dalam proses enkulturasi budaya pesantren sebagai upaya pembebasanan patriakisme Islam. Pelembagaan secara budaya tatanan sosial pesantren yang bias gender melalui humor dapat dieliminasi melalui penguatan pada agen-agen budaya agar berdasar pada nilai-nilai yang menghargai kesetaraan gender. Keberdayaan dan kompetensi perempuan yang setara dengan laki-laki menjadi topik-topik humor akan mengurangi stereotip, objektifikasi, dan peminggiran perempuan.

\section{Daftar Pustaka}

Anshari, Dadang S (Ed.) dkk. 1997. Membincangkan Feminisme, refleksi muslimah atas peran sosial wanita. Bandung: Pustaka Hidayah.

Bastcom Barudak Santri Comedi, 2010. Humor-Humor Pesantren. Tasikmalaya: Pesantren Miftahul Huda.

Bruinessen, Martin Van. 1994. Kitab Kuning Pesantren dan Tarekat. Bandung: Mizan.

Carson, Fiona. 2010. Feminisme dan tubuh, dalam Sarah (Ed.) Pengantar Mehamami Feminisme dan Postfeminisme (hlm. 147-162). Jogyakarta: Jalasutra.

Crawford, Mary. 2003. Gender and humor in social context. Journal of Pragmatics 35(9), 1413-1430.

Gilbert, Joanne. R. 2004. Performing Marginality: Humor, Gender, and Cultural Critique, Wayne State University Press.

Gunning, Barbara L., 2001. The role that humor plays in shaping organizational culture, Theses and Dissertations. Paper 1568. The University of Toledo.

Hasyim, Syafiq. 2010. Bebas Dari Patriakhisme dan Islam. Depok: Kata Kita.

Hughes, Christina. 2002. Key Concepts in Feminist Theory and Research. SAGE Publications London: Thousand Oaks.

Jackson, Stevi. 2009. Membentuk Teori Gender dan Seksualitas, dalam Pengantar Teori-Teori Feminis Kontemporer (hlm. 21-55). Bandung: Jalasutra.

el Harakah Jurnal Budaya Islam Vol. 19 No.1 Tahun 2017 
Marhumah, Ema. 2015. The roots of gender bias: misogynist hadiths in pesantrens. Indonesian Journal of Islam and Muslim Societies 5(2), 283-304.

Mughits, Abdul. 2008. Kritik Nalar Fiqh Pesantren, Jakarta: Prenada Media Group.

Reinharz, Shulamit. 2005. Metode-metode feminis dalam Penelitian Sosial. Terj. Lebona Rahman. Jakarta: Women Research Institut.

Talbot, Mary M. 2010. Feminisme dan Bahasa, dalam Sarah Gamble (Ed.) Pengantar Mehamami Feminisme dan Postfeminisme (hlm. 177-186). Jogyakarta: Jalasutra.

Tohir, AM. 2007. Pernak-Pernik Bahasa Sunda: Pamekar Bahasa Sunda, Bekel Pangjajap Acara, Upacara Akad Nikah. (ed. 2). Tasikmalaya: Pesantren Miftahul Huda. 